\title{
Allelopathy by extracts of Caatinga species on melon seeds
}

\author{
Alelopatia de extratos de espécies da caatinga sobre \\ sementes de meloeiro
}

\author{
Andreya Kalyana de Oliveira ${ }^{1}$; Maria de Fatima Barbosa Coelho ${ }^{2 *}$; \\ Salvador Barros Torres ${ }^{3}$; Francisco Ésio Porto Diógenes ${ }^{4}$
}

\begin{abstract}
The melon crop is of great socioeconomic importance in Brazil and some species from the Caatinga biome show allelopathic effects on other species. The aim of this study was to assess leaf and seed extracts of cumaru (Amburana cearensis (Allemao) A.C. Sm.), the jujube tree (Zizyphus joazeiro Mart.), Jucá (Caesalpinia ferrea Mart. Ex. Tul. Var. Ferrea) and mulungu (Erythrina velutina Willd.) on the emergence of melon seeds (Cucumis melo L.). Leaves and seeds were used to produce extracts for each species at concentrations of a) $1 \%$, b) $0.5 \%$ c) $0.25 \%$, d) $0.125 \%$ and e) $0 \%$ (control). The experiment was conducted with each extract type and its respective concentrations in a completely randomized design, with four replicates, each of 20 seeds. The percentage emergence and rate index, percentage of abnormal seedlings, seedling dry matter and seedling shoot and root length were assessed. Seed extracts of $A$. cearensis prevented melon germination, whereas the other extracts had no effect on this variable. Leaf extracts of $A$. cearensis and leaf and seed extracts of $Z$. joazeiro, C. ferrea and E. velutina resulted in abnormal melon seedlings. The percentage of abnormal melon seedlings exceeded $30 \%$ when treated with $C$. ferrea seed extract at the highest concentration. Most extracts did not affect seedling dry matter, but $E$. velutina leaf and seed extract increased the dry matter accumulation of melon seedlings and $Z$. joazeiro seed extract decreased dry matter accumulation at a concentration of $0.25 \%$. The highest concentrations of mulungu and jucá leaf extracts promoted the shoot growth of melon seedlings. The extract from E. velutina seeds negatively affected root length compared to the control, similar to the effect of $C$. ferrea and E. velutina leaf extracts at the highest concentrations. Extracts of different organs of Caatinga plants can affect the emergence and characteristics related to seedling growth, depending on the concentration. Most extracts did not affect germination or the emergence rate index, but affected seedling growth.
\end{abstract}

Key words: Cucumis melo L. Amburana cearensis. Ziziphus joazeiro. Caesalpinia férrea. Erythrina velutina.

\section{Resumo}

A cultura do melão tem grande importância socioeconômica no Brasil e algumas espécies do bioma Caatinga têm ação alelopática sobre outras espécies. O objetivo do trabalho foi avaliar os extratos de folhas e sementes de cumaru (Amburana cearensis (Allemao) A.C. Sm.), juazeiro (Zizyphus joazeiro Mart.) jucá (Caesalpinia ferrea Mart. ex. Tul. var. ferrea) and mulungu (Erythrina velutina Willd.) na emergência de sementes de melão (Cucumis melo L.). Os tipos de extratos foram os de folhas e sementes para cada espécie em concentrações de a) $1 \%$, b) $0,5 \%$, c) $0,25 \%$, d) $0,125 \%$ e e) $0 \%$ (testemunha).

1 Pesquisadora Dra ${ }^{\mathrm{a}}$, Universidade Federal Rural do Semi-Árido, UFERSA, Mossoró, RN, Brasil. E-mail: oliver_andreya@yahoo. com.br

2 Prof ${ }^{a}$, Titular, Universidade Federal de Mato Grosso, UFMT, Cuiabá, MT, Brasil. E-mail: coelhomfstrela@gmail.com

3 Prof. Colaborador, Universidade Federal Rural do Semi-Árido, UFERSA, Mossoró, RN, Brasil. E-mail: sbtorres@ufersa.edu.br

4 Pesquisador, Mestre, UFERSA, Mossoró, RN, Brasil. E-mail: esioporto@gmail.com

Author for correspondence 
Cada tipo de extrato com suas respectivas concentrações constituiu um experimento que foi conduzido em delineamento experimental inteiramente casualizado com quatro repetições de 20 sementes. Foram avaliadas a porcentagem e índice de velocidade de emergência, porcentagem de plântulas anormais, massa seca da plântula, comprimento da parte aérea e raiz da plântula. Os extratos de sementes de $A$. cearensis impediram a germinação de melão e os demais extratos não apresentaram efeitos sobre esta variável. Os extratos de folhas de A. cearensis, de folhas e sementes de Z. joazeiro, de C. ferrea e de E. velutina resultaram em plântulas anormais de melão. A porcentagem de plântulas anormais chegou a mais de $30 \%$ no extrato de sementes de $C$. ferrea na sua maior concentração. A maioria dos extratos não afetou a massa seca da plântula, mas no extrato de folhas e de sementes de E. velutina, houve maior acúmulo de massa seca nas plântulas de melão, e no extrato de sementes de $Z$. joazeiro a partir da concentração de $0,25 \%$ diminuiu o acúmulo de massa seca. A maior concentração do extrato das folhas de mulungu e do extrato de folhas de jucá favoreceu o crescimento da parte aérea de plântulas de meloeiro. $\mathrm{O}$ extrato de sementes de E. velutina afetou negativamente o comprimento da raiz em relação à testemunha, e os extratos de folhas de $C$. ferrea e de E. velutina na maior concentração também tiveram esse efeito. Os extratos de diferentes órgãos das plantas da Caatinga, dependendo da concentração, podem afetar tanto a emergência como as características relacionadas ao crescimento da plântula. A maioria dos extratos não afetaram a germinação e o IVE, mas tiveram efeitos no crescimento das plântulas.

Palavras-chave: Cucumis melo L. Amburana cearensis. Ziziphus joazeiro. Caesalpinia ferrea. Erythrina velutina.

\section{Introduction}

The positive or negative interference of compounds of secondary metabolism produced by plants and released into the surroundings is known as "allelopathy". The effect of allelopathy on the development of another plant can be indirect, by transformation in the soil, or by microorganism activity (INDERJIT et al., 2011).

Secondary metabolites or allelochemicals have been found in all plant organs and tend to accumulate in the leaves. The release of these compounds can occur via root exudation, leaching or volatilization (REIGOSA et al., 2013). The leaf is the most metabolically active plant organ and thus, possesses a high allelochemical diversity (TUR et al., 2010).

In allelopathy studies with Caatinga species, it was found that cumaru bark (Amburana cearensis (Allemao) A. C. Sm.) extracts were most active in affecting the germination of seeds of sorghum (Sorghum bicolor (L.) Moench) (SILVA et al., 2006); Zizyphus joazeiro Mart. fruit pulp and peel extracts had adverse allelopathic effects on the germination of lettuce seeds, depending on the concentration (COELHO et al., 2011); mulungu (Erythrina velutina Willd.) seed extract reduced the germination of L. sativa seeds, and flower and bark extracts were phytotoxic to lettuce seeds and seedlings (OLIVEIRA et al., 2012a); and jucá (Caesalpinia ferrea Mart. ex Tul. var. ferrea) pod and leaf extracts, obtained at a high temperature $\left(100^{\circ} \mathrm{C}\right)$, reduced the percentage of lettuce seed germination compared to the controls and additionally, caused a high percentage of abnormal seedlings (OLIVEIRA et al., 2012b).

Most allelopathy studies use lettuce as a test species and assess seed germination; however, the use of other species is also necessary, as they might respond differently. In addition, it is important to understnad the behavior of a species outside laboratory conditions and on different substrates, because one of the applications of allelopathy is the potential control of invasive species using extracts. In a study by Carvalho et al. (2002) shoot aqueous extract of velvet bean (Stizolobium aterrimum) had an allelopathic effect on coco-grass (Cyperus rotundus), causing growth reduction, a stabilization of tuber multiplication and a lower emergence rate index.

The melon crop (Cucumis melo L.) is of great socioeconomic importance in Brazil and has played 
a crucial role in Brazilian fruit exports. It ranks third-highest in the list of sales, accounting for 134.1 million USD, and representing $15.7 \%$ of the total fruit export market. In 2013, Brazil exported 181.7 tonnes of melon, an increase of $7.2 \%$ compared to 2011 (IBRAF, 2015). Brazil's Northeastern region accounts for most of the production (94.99\%), and the states of Rio Grande do Norte, Ceará, Bahia and Pernambuco were responsible for the increase in production. The state of Rio Grande do Norte producing 258,938 tonnes, i.e., $51.86 \%$ of the national production and more than any other state. Productivity in this state has reached 31.1 t.ha $^{-1}$, exceeding the Brazilian mean, which is 25.4 t.ha $^{-1}$ (IBGE, 2013).

Thus, taking into account the importance of the melon crop in Northeastern Brazil, and based on the demonstration that Caatinga species have allelopathic effects on test species, the aim of this study was to assess the effects of cumaru, jujube tree, jucá and mulungu leaf and seed extracts on the emergence of seedlings of melon plants.

\section{Material and Methods}

The experiment was conducted at the Chemical Laboratory of the State University of Rio Grande do Norte (UERN), and in the Seed Analysis Laboratory of the Department of Plant Sciences, Federal Rural University of the Semiarid (UFERSA), in the municipality of Mossoró, from November 2011 to May 2013. Melon seeds of the Iracema cultivar were used, which showed 100\% germination. The extracts used derived from A. cearensis, $Z$. joazeiro, $C$. ferrea and E. velutina leaves and seeds.

Hydroalcoholic extracts were made in the UERN Chromatography Laboratory, Mossoró, RN state. Initially, a $70 \%(\mathrm{v} / \mathrm{v})$ ethanol solution was prepared, which was adjusted using a Gay-Lussac $20{ }^{\circ} \mathrm{C}$ alcohol meter. To extract the material, $480 \mathrm{~g}$ seeds and $135 \mathrm{~g}$ leaves were dried at $50{ }^{\circ} \mathrm{C}$ for $48 \mathrm{~h}$ and then ground in an electric mill. Each material was placed in 1-L volume frosted glass container, and
600 or $800 \mathrm{~mL}$ hydroalcoholic solution was added to each container, to produce seed and leaf extracts, respectively.

For the subsequent extractions, the volume of hydroalcoholic solution added varied according to the amount of material removed in each extract, so that the container was always filled to its volume capacity. Six sequential extractions were performed, at three- to four-day intervals. The material was subjected to constant agitation, to enhance solvent action.

Each extract was filtered and the liquid fraction was evaporated using a rotary evaporator (ethanol evaporation), resulting in a paste. The paste was placed into a beaker and was stirred using a magnetic stirrer at $60^{\circ} \mathrm{C}$ on a porcelain plate coupled to a water container. The liquid was gradually evaporated until the dry matter from each extract was obtained (115 $\mathrm{g}$ seed matter and $43 \mathrm{~g}$ leaf matter). The vessels containing the dry matter were wrapped in plastic wrap and stored at $7{ }^{\circ} \mathrm{C}$, until aqueous extracts were produced.

To prepare crude extracts, $20 \mathrm{~g}$ dry matter from the seeds of leaves of each species was weighed on a balance (to $0.0001 \mathrm{~g}$ precision) and 2,000 $\mathrm{mL}$ distilled water was added, resulting in a concentration of $1 \%$ i.e., for each gram of solute (extract dry matter), $100 \mathrm{~mL}$ water was used. The mixture was treated with ultrasound for $35 \mathrm{~min}$, to increase the solubility of non-polar constituents. The mixture was then filtered through a glass funnel sealed with cotton. The filtered mixture was placed in a frosted glass container, to reduce the effect of light and to minimize photobleaching. The $\mathrm{pH}$ and electrical conductivity of the extracts were determined and the osmotic potential was calculated using the formula proposed by Ayers and Westcot (1994): PO $($ ATM $)=0.36 *$ CE. Subsequently, the crude extracts were stored in the refrigerator until the bioassays were conducted.

Different concentrations of extracts have different effects on plant morphology and physiology. Therefore, this study sought methods in 
the literature that used the closest doses to natural conditions. Subsequently, four concentrations were selected $(1 \%, 0.5 \%, 0.25 \%$ and $0.125 \%)$, and these dilutions were obtained from the $1 \%$ extracts.

The extract types were as follows: a) $A$. cearensis leaf extract b) $A$. cearensis seed extract c) $Z$. joazeiro leaf extract, d) $Z$. joazeiro seed extract, e) $C$. ferrea leaf extract, f) C. ferrea seed extract, g) E. velutina leaf extract h) E. velutina seed extract. The following concentrations pf extracts were used: a) $1 \%$, b) $0.5 \%$, c) $0.25 \%$, d) $0.125 \%$ and e) $0 \%$ as a control. Each extract type and concentration treatment was conducted in a completely randomized design, with four replicates, each of 20 seeds. Regression analysis of the variance was performed using the SISVAR statistical program (FERREIRA, 2008).

Each plot consisted of a plastic box $(17 \mathrm{~cm}$ depth, $9.5 \mathrm{~cm}$ width and $4.3 \mathrm{~cm}$ height) that was sterilized with alcohol $\left(92.8^{\circ}\right)$ and contained $400 \mathrm{~g}$ washed and sterilized sand (BRASIL, 2009). The experimental units were wetted with $50 \mathrm{~mL}$ extract and their contents were turned upside-down, to ensure moisture uniformity within the plot, which was leveled using a spatula. Subsequently, circular holes $1 \mathrm{~cm}$ and $6.5 \mathrm{~cm}$ deep were made, and the 20 seeds were distributed evenly within the holes. The plastic boxes were placed in a germinator at $25^{\circ} \mathrm{C}$ with a 24-h photoperiod for eight days.

Cotyledon emergence was used as a seedling emergence criterion. Final assessments of the seedling were performed on the eighth day after sowing, when they were classified as normal or abnormal, according to the criteria described in the Rules for Seed Analysis (BRASIL, 2009). Shoot and root measurements of all normal seedlings were made with a digital caliper. The dry matter of normal seedlings was obtained by placing in a forced-air oven at $65^{\circ} \mathrm{C}$ for $24 \mathrm{~h}$. The material was removed from the oven and placed in a desiccator for $30 \mathrm{~min}$ to cool, and was then weighed.

The variables analyzed included the percentage emergence, the number of normal and abnormal seedlings, root length (distance in $\mathrm{mm}$ from the collar to the meristem apex) and shoot length (distance in $\mathrm{mm}$ from the collar to the apex) and the number of roots. The emergence rate index (ERI) was calculated according to Maguire (1962), using the following formula:

$$
\mathrm{ERI}=\frac{\mathrm{G} 1}{\mathrm{~N} 1}+\frac{\mathrm{G} 2}{\mathrm{~N} 2}+\frac{\mathrm{G} 3}{\mathrm{~N} 3}+\cdots+\frac{\mathrm{Gn}}{\mathrm{Nn}},
$$

where G1, G2, Gn are the number of germinated seeds computed in the first, second and last count and N1, N2, Nn are number of days from sowing to the first, second and last counts.

The different types of extracts were within the normal osmotic potential ( 0 to -0.09$)$ and $\mathrm{pH}$ (4.7 to $6.7)$ values. Therefore, these factors did not account for changes in lettuce germination. Under normal conditions, the $\mathrm{pH}$ should be between 4 and 7, and the osmotic potential (MPa) should be below -0.2 Gatti et al. (2004) recommended that the osmotic potential of extracts in germination tests should not exceed values of $-0.2 \mathrm{MPa}$, since extracts might contain solutes that alter water properties, resulting in an osmotic pressure different from zero in the solution (VILLELA et al., 1991). Optimum values for the germination of most plant species are between 6.0 and 7.5 (LAYNEZ-GARSABALL; MENDEZ-NATERA, 2006).

\section{Results and Discussion}

The melon emergence percentage and emergence rate index (ERI) were not affected by most extracts or concentrations (Table 1 and 2). However, $A$. cearensis seed extract prevented melon germination and emergence at the highest concentrations (1, 0.5 and $0.25 \%$ ). Amburana cearensis seed extract did not affect emergence percentage, germination rate and seedling dry matter at a concentration of $0.125 \%$. This extract caused $12.5 \%$ abnormal seedlings, according to the criteria of Brasil (2009), and reduced mean seedling shoot and root length values (8.44 and $9.09 \mathrm{~cm}$, respectively) compared to the control (11.86 and $11.45 \mathrm{~cm}$, respectively). 
Table 1. Average values of percentage of emergence of melon (Cucumis melo L.) extracts at different concentrations of leaves and seeds of Amburana cearensis, Ziziphus joazeiro, Caesalpinia ferrea and Erythrina velutina.

\begin{tabular}{|c|c|c|c|c|c|c|c|}
\hline \multirow{3}{*}{$\begin{array}{l}\text { Concentration of } \\
\text { extract }(\%)\end{array}$} & \multicolumn{7}{|c|}{ Extract types } \\
\hline & \multirow{2}{*}{$\begin{array}{c}\text { Amburana cearensis } \\
\text { Leaves }\end{array}$} & \multicolumn{2}{|c|}{ Ziziphus joazeiro } & \multicolumn{2}{|c|}{ Caesalpinia ferrea } & \multicolumn{2}{|c|}{ Erythrina velutina } \\
\hline & & Leaves & Seeds & Leaves & Seeds & Leaves & Seeds \\
\hline 1,0 & 96,2 & 88,8 & 88,7 & 100,0 & 100,0 & 88,7 & 97,5 \\
\hline 0,5 & 96,2 & 93,8 & 91,2 & 97,5 & 98,7 & 93,7 & 100,0 \\
\hline 0,25 & 98,7 & 90,0 & 97,5 & 98,7 & 100,0 & 98,7 & 100,0 \\
\hline 0,125 & 100,0 & 97,5 & 100,0 & 97,5 & 98,7 & 100,0 & 100,0 \\
\hline 0 & 100,0 & 100,0 & 100,0 & 100,0 & 100,0 & 100,0 & 100,0 \\
\hline
\end{tabular}

Table 2. Emergency rate index of melon (Cucumis melo L.) extracts at different concentrations of leaves and seeds of Amburana cearensis, Ziziphus joazeiro, Caesalpinia ferrea and Erythrina velutina.

\begin{tabular}{cccccccc}
\hline \multirow{2}{*}{\begin{tabular}{c} 
Concentration of $\begin{array}{c}\text { Extract types } \\
\text { extract (\%) }\end{array}$ \\
\cline { 2 - 7 }
\end{tabular}} & Amburana cearensis & \multicolumn{7}{c}{ Ziziphus joazeiro } & Caesalpinia ferrea & \multicolumn{2}{c}{ Erythrina velutina } \\
\cline { 2 - 7 } & Leaves & Leaves & Seeds & Leaves & Seeds & Leaves & Seeds \\
\hline 1,0 & 3,5 & 3,5 & 3,4 & 4,1 & 3,4 & 3,9 & 4,0 \\
0,5 & 3,5 & 3,5 & 3,7 & 4,1 & 3,7 & 4,4 & 4,4 \\
0,25 & 4,0 & 4,0 & 3,9 & 4,4 & 3,9 & 4,7 & 4,5 \\
0,125 & 4,0 & 4,0 & 3,8 & 4,1 & 3,8 & 4,7 & 4,8 \\
0 & 3,6 & 3,6 & 3,8 & 4,2 & 3,8 & 4,7 & 4,7 \\
\hline
\end{tabular}

According to Ferreira and Borghetti (2004), allelopathic effects are more evident in characteristics related to growth than in the germination process. Oliveira et al. (2012a) confirmed this for Caatinga species with $E$. velutina flower, bark and seeds extracts and for C. ferrea extracts (OLIVEIRA et al., 2012b) and for Z. joazeiro extracts (Oliveira et al. (2012c). This study supports the findings of Ferreira and Borghetti (2004) for melon emergence in sand, which were consequences of the germination process. Cumaru seed extract showed allelopathic effects on abnormal melon seedling emergence and formation, possibly due to the coumarin in seeds, which is recognized as a germination inhibitor (BERRIE et al., 1968).

Amburana cearensis leaf extract and Z. joazeiro, $C$. ferrea and E. velutina leaf and seed extracts caused melon seedlings to germinate abnormally (Figure 1). Seedlings showed the absence of absorbent hairs in the root, a necrotic, dark and hard root apex, deformed roots and negative gravitropism, i.e., the roots did not grow into the substrate, but to its upper part. The percentage of abnormal seedlings exceeded $25 \%$ in $A$. cearensis and $Z$. joazeiro leaf extracts, and $30 \%$ at the highest concentration of $C$. ferrea seed extract.

Root apex hardening and darkening represent evidence of morphological and anatomical changes caused by phytotoxins (CRUZ-ORTEGA et al., 1998). Several authors have also observed these effects in lettuce seeds, such as Felix (2007) with A. cearensis seed aqueous extracts, Oliveira et al. (2012a) with E. velutina extracts, Oliveira et al. (2012c) with $Z$. joazeiro seed aqueous extracts, Silveira et al. (2012) with Mimosa tenuiflora (Wild) Poir.) bark extract and Silveira et al. (2011) with $M$. tenuiflora seed aqueous extracts.

There was no regression model adjustment to seedling dry-matter data. However, the mean data are summarized in Table 3. Dry matter accumulated in melon seedlings with E. velutina leaf and seed extract; however, $Z$. joazeiro seed extract decreased dry matter accumulation at concentrations greater than 0.25. In the other extracts, the effect was similar to that in the control. 
Figure 1. Percentage of abnormal seedlings of melon (Cucumis melo L.) at different concentrations of extracts of leaves and seeds of cumaru (Amburana cearensis), juazeiro (Ziziphus joazeiro), jucá (Caesalpinia ferrea) and mulungu (Erythrina velutina).

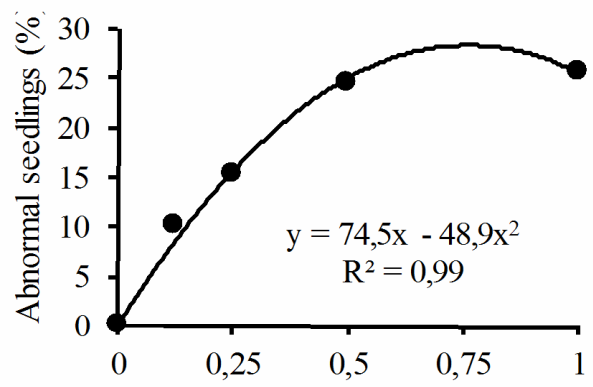

Conc.of leaves extract of cumaru (\%)

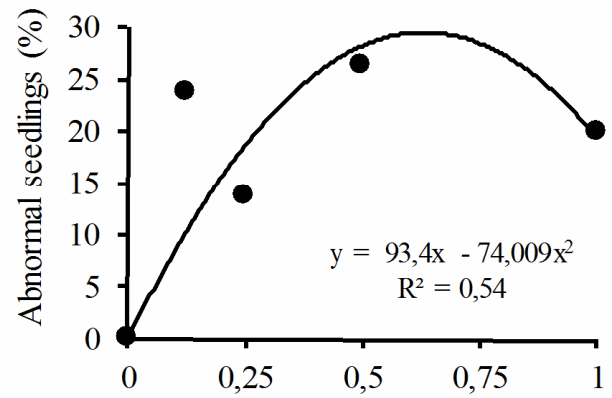

Conc. of leaves extract of juazeiro (\%)

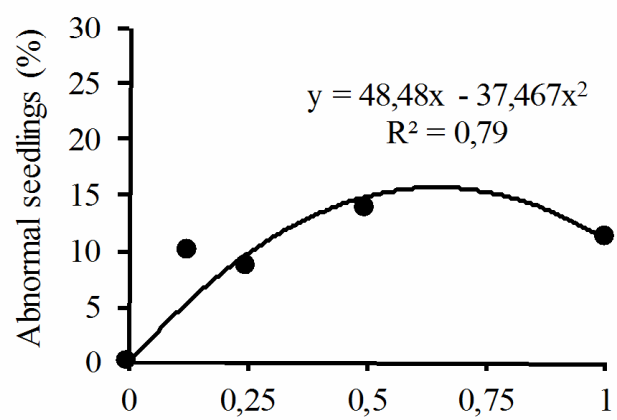

Conc. of leaves extract of jucá $(\%)$

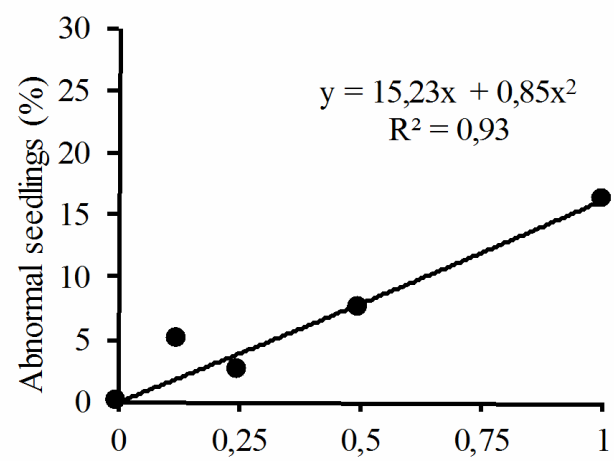

Conc. of leaves extract of mulungu (\%)

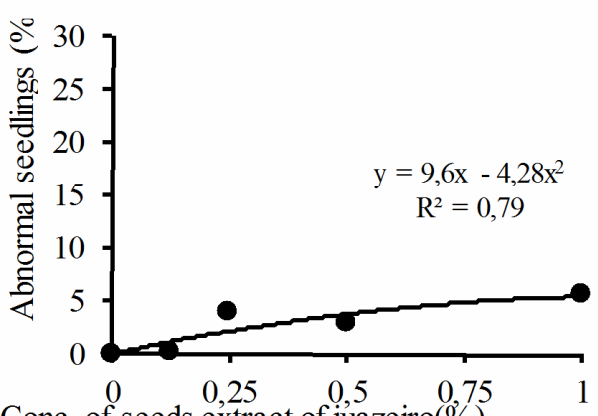

Conc. of seeds extract of juazeiro $(\%)$

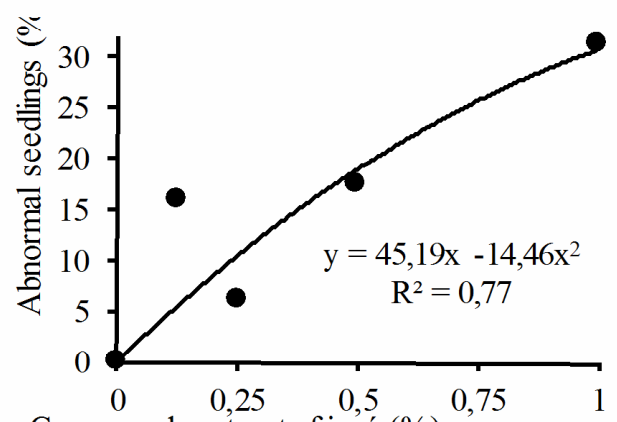

Conc. seeds extract of jucá (\%)

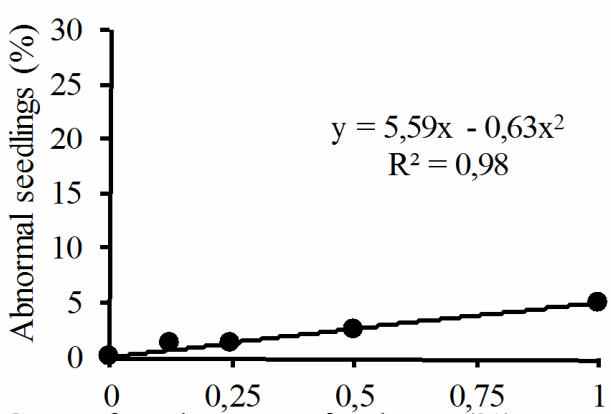

Conc. of seeds extract of mulungu $(\%)$ 
Table 3. Seedling dry matter (mg) of melon (Cucumis melo L.) at different concentrations of hydroalcoholic extracts of leaves and seeds of Amburana cearensis, Ziziphus joazeiro, Caesalpinia ferrea and Erythrina velutina.

\begin{tabular}{cccccccc}
\hline \multirow{2}{*}{$\begin{array}{c}\text { Concentration of } \\
\text { extract (\%) }\end{array}$} & \multicolumn{7}{c}{ Extract types } \\
\cline { 2 - 7 } & Amburana cearensis & \multicolumn{2}{c}{ Ziziphus joazeiro } & Caesalpinia ferrea & \multicolumn{2}{c}{ Erythrina velutina } \\
\cline { 2 - 7 } & Leaves & Leaves & Seeds & Leaves & Seeds & Leaves & Seeds \\
\hline 1,0 & 0,43 & 0,32 & 0,36 & 0,48 & 0,56 & 1,60 & 1,61 \\
0,5 & 0,48 & 0,46 & 0,43 & 0,44 & 0,62 & 1,76 & 1,57 \\
0,25 & 0,61 & 0,48 & 0,47 & 0,48 & 0,75 & 1,94 & 1,47 \\
0,125 & 0,57 & 0,45 & 0,60 & 0,41 & 0,73 & 1,68 & 1,21 \\
0 & 0,44 & 0,51 & 0,62 & 0,45 & 0,61 & 0,58 & 0,59 \\
\hline
\end{tabular}

Seedling dry matter is related to vigor and the establishment ability in the field, and the effect of E. velutina extracts on melon growth should be further investigated. Few studies report favorable effects for germination and growth in the presence of allelochemicals, although allelopathic activity can either benefit plant physiological processes or not. Centenaro et al. (2009) found that ethanolic crude extracts at concentrations of $0.6,0.4,0.3$, 0.2 and $0.05 \mathrm{mg}$ and the remaining hydroalcoholic fraction of $0.3 \mathrm{mg}$ in E. velutina seeds stimulated lettuce seed germination, but inhibited seedling growth. Silva et al. (2012) found that Barbados nut root extract (Jatropha curcas) caused a significant increase in the germination rate and stimulated rooting in soybean seedlings.

The highest concentrations of $E$. velutina and $C$. ferrea leaf extracts favored melon seedling shoot growth, but regression models could not be adjusted (Table 4). In the other experiments, regression analysis of the variance was not significant; however, $E$. velutina leaf and seed extracts negatively affected root length compared to the control, following the second degree polynomial regression model (Figure 2). Leaf extracts of $Z$. joazeiro and $C$. ferrea only showed this effect at the highest concentration (Table 5).

Table 4. Shoot length (mm) of melon (Cucumis melo L.) at different concentrations of hydroalcoholic extracts of leaves and seeds of Amburana cearensis, Ziziphus joazeiro, Caesalpinia ferrea and Erythrina velutina.

\begin{tabular}{cccccccc}
\hline \multirow{2}{*}{\begin{tabular}{c} 
Concentration of $\begin{array}{c}\text { Extract types } \\
\text { extract (\%) }\end{array}$ \\
\cline { 2 - 7 }
\end{tabular}} & Amburana cearensis & \multicolumn{2}{c}{ Ziziphus joazeiro } & Caesalpinia ferrea & \multicolumn{2}{c}{ Erythrina velutina } \\
\cline { 2 - 7 } & Leaves & Leaves & Seeds & Leaves & Seeds & Leaves & Seeds \\
\hline 1,0 & 13,55 & 13,54 & 12,50 & 14,78 & 11,23 & 16,94 & 12,94 \\
0,5 & 13,34 & 12,37 & 12,29 & 12,92 & 14,38 & 13,87 & 12,64 \\
0,25 & 12,36 & 14,46 & 13,77 & 11,28 & 13,01 & 14,48 & 13,51 \\
0,125 & 13,96 & 13,15 & 12,12 & 11,93 & 12,44 & 12,88 & 13,71 \\
0 & 11,92 & 12,12 & 12,05 & 13,47 & 13,44 & 13,61 & 13,48 \\
\hline
\end{tabular}

Table 5. Root length ( $\mathrm{mm}$ ) of melon (Cucumis melo L.) at different concentrations of hydroalcoholic extracts of leaves and seeds of Amburana cearensis, Ziziphus joazeiro and Caesalpinia ferrea.

\begin{tabular}{cccccc}
\hline \multirow{2}{*}{$\begin{array}{c}\text { Concentration of } \\
\text { extract (\%) }\end{array}$} & \multicolumn{5}{c}{ Extract types } \\
\cline { 2 - 5 } & Amburana cearensis & \multicolumn{2}{c}{ Ziziphus joazeiro } & \multicolumn{2}{c}{ Caesalpinia ferrea } \\
\cline { 2 - 5 } & Leaves & Leaves & Seeds & Leaves & Seeds \\
\hline 1,0 & 12,26 & 7,90 & 11,45 & 12,42 & 9,95 \\
0,5 & 12,56 & 10,58 & 11,12 & 13,13 & 10,97 \\
0,25 & 12,74 & 11,77 & 12,36 & 12,28 & 10,88 \\
0,125 & 13,05 & 12,72 & 12,45 & 12,21 & 11,19 \\
0 & 11,78 & 13,59 & 12,99 & 13,94 & 11,19 \\
\hline
\end{tabular}


Figure 2. Root length of melon (Cucumis melo L.) at different concentrations of hydroalcoholic extracts of leaves and seeds of mulungu (Erythrina velutina).

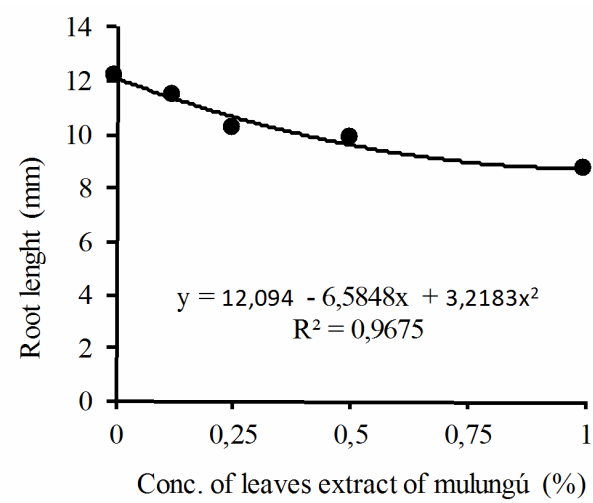

In studies with different species, roots were more sensitive to allelopathic extracts (BORELLA et al., 2009; HAIDA et al., 2010). There was a reduction in lettuce seedling root growth compared to the control when they were exposed to extracts from C. ferrea leaves (OLIVEIRA et al., 2012b) and Mimosa tenuiflora (Wild) Poir. bark (SILVEIRA et al., 2011). The greatest effect on root length was due to intimate contact between the roots and filter paper, which was treated with allelochemicals used in bioassays (CHUNG et al., 2001). These results can be interpreted by considering that as a result of selective and evolutionary processes, seeds are less sensitive to allelochemicals than seedlings (FERREIRA; ÁQUILA, 2000).

\section{Conclusions}

Seed extract of $A$. cearensis prevents melon seed emergence, whereas that of $E$. velutina inhibits melon seedling root growth and the leaf extract of $E$. velutina promotes shoot growth. Leaf extract of $A$. cearensis and leaf and seed extracts of $Z$. joazeiro, $C$. ferrea and E. velutina cause abnormalities in melon seedlings. Extracts of different plant organs might not affect emergence, depending on the concentration, but instead, might interfere with characteristics related to seedling growth.

\section{References}

AYERS, R. S.; WESTCOT, D. W. Water quality for

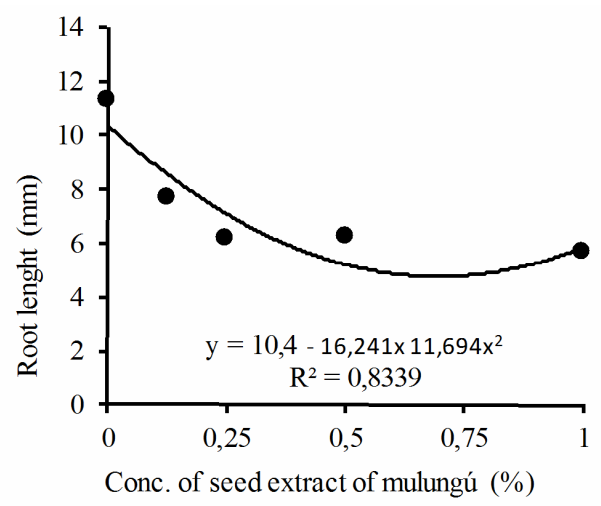

agriculture. Roma: FAO, 1994. 97 p. (FAO. Irrigation and Drainage Peper, 29).

BERRIE, A. M.; PARKER, B. A.; KNIGTS, W.; HEMDRIMN, M. R. Studies on lettuce seed germination. I. Coumarin induced dormancy. Phytochemistry, Washington, v. 7, n. 4, p. 567-573, 1968.

BORELLA, J.; WANDSCHEER, A. C. D.; BONATTI, L. C.; PASTORINI, L. H. Efeito alelopático de extratos aquosos de Persea americana Mill. sobre Lactuca sativa L. Revista Brasileira de Biociências, Porto Alegre, v. 7, n. 3, p. 260-265, 2009.

BRASIL. Ministério da Agricultura, Pecuária e Abastecimento. Regras para análise de sementes. Secretaria de Defesa Agropecuária. Brasília, DF: Mapa/ ACS, 2009. 395 p.

CARVALHO, G. J.; FONTANETTI, A.; CANÇADO, C. T. Potencial alelopático do feijão de porco (Canavalia ensiformes) e da mucuna-preta (Stilozobium aterrimum) no controle da tiririca (Cyperus rotundus). Ciência e Agrotecnologia, Lavras, v. 26, n. 3, p. 647-651, 2002.

CENTENARO, C.; CORRÊA, L. G. P.; KARAS, M. J.; VIRTUOSO, S.; DIAS, J. E. G.; MIGUEL, O. G.; MIGUEL, M. D. Contribuição ao estudo alelopático de Erythrina velutina Willd. Fabaceae. Revista Brasileira de Farmacognosia, João Pessoa, v. 19, n. 1, p. 304-308, 2009.

CHUNG, I. M.; AHN, J. K.; YUN, S. J. Assessment of allelopathic potential of barnyard grass (Echinochloa crusgall) on rice (Oriza sativa L.) cultivars. Crop Protection, Guildorf, v. 20, n. 10, p. 921-928, 2001.

COELHO, M. F. B.; MAIA, S. S. S.; OLIVEIRA, A. K.; DIÓGENES, F. E. P. Atividade alelopática de extrato de sementes de juazeiro. Horticultura Brasileira, Brasília, v. 29, n. 1, p. 108-111, 2011. 
CRUZ-ORTEGA, R.; ANAYA, A. L.; HERNÁNDEZBAUTISTA, B. E.; LAGUNA-HERNÁNDEZ, G. Effects of allelochemical stress produced by Sicyios deppei on seedling root ultrastructure of Phaseolus vulgaris e Curcubita ficifolia. Journal of Chemical Ecology, Lexington, v. 24, n. 12, p. 2039-2057, 1998.

FELIX, R. A. Z.; ONO, E. O.; SILVA, C. P.; RODRIGUES, J. D.; PIERI, C. Efeitos alelopáticos da Amburana cearensis L. (Fr.All.) AC Smith na germinação de sementes de alface (Lactuca sativa L.) e de rabanete (Raphanus sativus L.). Revista Brasileira de Biociências, Porto Alegre, v. 5, p. 138-140, 2007. Suplemento 2.

FERREIRA, A. G.; AQUILA, M. E. Alelopatia: uma área emergente da ecofisiologia. Revista Brasileira de Fisiologia Vegetal, São Paulo, v. 12, p. 175-204, 2000. Número Especial.

FERREIRA, A. G.; BORGHETTI, F. Germinação: do básico ao aplicado. Porto Alegre: Ed. Artimed, 2004. 323 p.

FERREIRA, D. F. SISVAR: um programa para análises e ensino de estatística. Revista Symposium, Lavras, v. 6, n. 6 , p. 36-41, 2008.

GATTI, A. B.; PEREZ, S. C. J. G.; LIMA, M. I. S. Efeito alelopático de Aristolochia esperanzae O. Kuntze na germinação e no crescimento de Lactuca sativa L. e Raphanus sativus L. Acta Botanica Brasilica, São Paulo, v. 8, n. 3, p. 459-472, 2004.

HAIDA, K. S.; COELHO, S. E. M.; HAAS-COSTA, J.; VIECELLI, A. A.; ALEKCEVETCH, J. C.; BARTH, E. F. Efeito alelopático de Achillea millefolium L. sobre sementes de Lactuca sativa L. Revista em Agronegócios e Meio Ambiente, Maringá, v. 3, n. 1, p. 101-109, 2010.

INDERJIT, D. A.; WARDLE, R. K.; RAGAN, M. C. The ecosystem and evolutionary contexts of allelopathy. Trends in Ecology and Evolution, Cambridge, v. 26, n. 12, p. 655-662, 2011.

INSTITUTO BRASILEIRO DE FRUTAS - IBRAF. Panorama da cadeia produtiva de frutas no Brasil 2012 com projeção para 2013. São Paulo: IBRAF, 2015. Disponível em: <http://www.ibraf.org.br>. Acesso em: 20 set. 2015.

INSTITUTO BRASILEIRO DE GEOGRAFIA E ESTATÍSTICA - IBGE. Dados de produção 2013. Rio de Janeiro: IBGE, 2013. Disponível em: <http://www. ibge.gov.br/estadosat/temas.php?sigla=ba\&tema=lavour atemporaria2013 > . Acesso em: 17 set 2015.

LAYNEZ-GARSABALL, J. A.; MENDEZ-NATERA, J. R. Efectos de extractos acuosos del follaje del corocillo (Cyperus rotundus L.) sobre la germinación de semillas y el crecimiento de plântulas de ajonjolí (Sesamum indicum L.) CV. Idesia, Arica, v. 24, n. 2, p. 61-75, 2006.
MAGUIRE, J. D. Speed of germination-aid in selection evaluation for seedling emergence and vigor. Crop Science, Madison, v. 2, n. 2, p. 176-177, 1962.

OLIVEIRA, A. K.; COELHO, M. F. B.; MAIA, S. S. S.; DIÓGENES, F. E. P. Atividade alelopática de extratos de diferentes orgãos de Caesalpinia ferrea na germinação de alface. Ciência Rural, Santa Maria, v. 42, n. 8, p. 1397-1403, 2012b.

OLIVEIRA, A. K.; COELHO, M. F. B.; MAIA, S. S. S.; DIÓGENES, F. E. P.; MEDEIROS FILHO, S. Atividade alelopática de extratos de diferentes partes de juazeiro (Ziziphus joazeiro Mart. - Rhamnaceae). Acta Botanica Brasilica, Feira de Santana, v. 26, n. 3, p. 692-698, 2012c.

Alelopatia de extratos de diferentes órgãos de mulungu na germinação de alface. Horticultura Brasileira, Brasília, v. 30, n. 3, p. 478-481, 2012a.

REIGOSA, M.; GOMES, A. S.; FERREIRA, A. G.; BORGHETTI, F. Allelopathic research in Brazil. Acta Botanica Brasilica, São Paulo, v. 27, n. 4, p. 629-646, 2013.

SILVA, P. S. S.; FORTES, A. M. T.; PILATTI, D. M.; BOIAGO, N. P. Atividade alelopática do exsudato radicular de Jatropha curcas L. sobre plântulas de Brassica napus L., Glycine max L., Zea mays L. e Helianthus annuus L. Insula Revista de Botânica, Florianópolis, v. 1, n. 41, p. 32-41, 2012.

SILVA, W. A.; NOBRE, A. P.; LEITES, A. P.; SILVA, M. S. C.; LUCAS, R. C.; RODRIGUES, O. G. Efeito alelopático de extrato aquoso de Amburana cearensis A. Smith na germinação e crescimento de sementes de sorgo (Sorghum bicolor L.). Agropecuária Científica no SemiÁrido, Patos, v. 2, n. 1, p. 48-54, 2006.

SILVEIRA, P. F.; MAIA, S. S. S.; COELHO, M. F. B. Atividade alelopática do extrato aquoso de sementes de jurema preta na germinação de alface. Revista de Ciências Agrárias, Manaus, v. 54, n. 2, p. 101-106, 2011.

Potencial alelopático do extrato aquoso de $\overline{\text { cascas }}$ de jurema preta no desenvolvimento inicial de alface. Revista Caatinga, Mossoró, v. 25, n. 1, p. 20-27, 2012.

TUR, C. M.; BORELLA, J.; PASTORINI, L. H. Alelopatia de extratos aquosos de Duranta repens sobre a germinação e o crescimento inicial de Lactuca sativa e Lycopersicum esculentum. Revista Biotemas, Florianópolis, v. 23, n. 2, p. 13-22, 2010.

VILLELA, F. A.; DONI FILHO, L.; SEQUEIRA, E. L. Tabela de potencial osmótico em função da concentração de polietileno glicol 6000 e da temperatura. Pesquisa Agropecuária Brasileira, Brasília, v. 26, n. 11, p. 19571968, 1991. 
